\title{
Length-weight relationship for two fish species from Ipanema National Forest, São Paulo state, Brazil
}

\author{
Relação peso-comprimento de duas espécies de peixes da Floresta \\ Nacional de Ipanema, SP, Brasil
}

Relación longitud-peso para dos especies de peces del bosque nacional Ipanema, estado de São Paulo, Brasil

Soinski TA, CostaMS, BrambillaEM, Smith WS. Length-weight relationship for two fish species from Ipanema National Forest, São Paulo state, Brazil. Rev Colombiana Cienc Anim. Recia. 2020; 12(2):e749. https://doi.org/10.24188/recia.v12.n2.2020.749

Universidad de Sucre, Colombia

Los autores permiten a RECIA reimprimir el material publicado en él. En caso de que un autor quiera traducir o usar una publicación parcial o completa de nuestro Diario, el autor debe obtener un permiso por escrito del editor de la revista.

Copyright (C) 2020. El (los) autor (es), Revista Colombiana de Ciencia Animal - RECIA. 2020. Este es un artículo de acceso abierto distribuido bajo los términos de Creative Commons Attribution 4.0 (https://creativecommons.org/licenses/by-nc-sa/4.0/), El uso, distribución o reproducción está permitido, siempre que se acrediten al autor original y al propietario del copyright y que se cite la publicación original en esta revista, de acuerdo con la práctica académica aceptada. No se permite el uso, distribución o reproducción que no cumpla con estos términos.

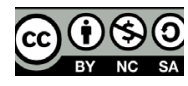




\title{
Length-weight relationship for two fish species from Ipanema National Forest, São Paulo state, Brazil
}

\author{
Relação peso-comprimento de duas espécies de peixes da Floresta Nacional de Ipanema, \\ SP, Brasil
}

\author{
Relación longitud-peso para dos especies de peces del bosque nacional Ipanema, \\ estado de São Paulo, Brasil
}

Thais A. Soinski. M.Sc.

Universidade Paulista. Laboratório de Ecologia Estrutural e Funcional de

Ecossistemas, Sorocaba. Brasil.

Universidade de São Paulo. Escola de Engenharia de São Carlos / EESC,

Centro de Recursos Hídricos e Estudos Ambientais / CRHEA, Programa de

Pós-Graduação em Ciências da Engenharia Ambiental, , Itirapina (SP), Brasil.

thaissoinski@outlook.com

(iD)https://orcid.org/0000-0003-4147-0212

Matheus S. Costa.

Universidade Paulista. Laboratório de Ecologia Estrutural e Funcional

de Ecossistemas, Sorocaba. Brasil.

matheussouza18075@hotmail.com

iD https://orcid.org/0000-0002-6182-0331

Eduardo M. Brambilla. Ph.D.

Universidade Estadual Paulista "Júlio de Mesquita Filho", Departamento de Zoologia, Botucatu, São Paulo, Brasil.

eduardo.brambilla@gmail.com

iD https://orcid.org/0000-0003-2901-2526

\section{Welber S. Smith. Ph.D.}

Universidade Paulista. Laboratório de Ecologia Estrutural e Funcional de Ecossistemas, Sorocaba. Brasil.

Universidade de São Paulo. Escola de Engenharia de São Carlos / EESC, Centro de Recursos Hídricos e Estudos Ambientais / CRHEA, Programa de Pós-Graduação em Ciências da Engenharia Ambiental, Itirapina (SP), Brasil.

Parque Água Branca, Programa de Posgrado en Acuicultura y Pesca,

Barra Funda, SP São Paulo, Brasil

welbersmith@uol.com.br

(D)https://orcid.org/0000-0001-9803-7394

DOI: https://doi.org/10.24188/recia.v12.n2.2020.749

\begin{abstract}
The weight-length relationship is an important tool in the studies of fish biology, physiology and ecology, as this relationship is useful for determining weight and biomass, indicating conditions and allowing comparisons between the growth of different populations, in addition, this relationship can also be used to assess the degree of health of species in the environment. The objective of this study was to present unpublished data on the weight-length relationship (LWRs) of the species Hypostomus ancistroides and Corydoras flaveolus. The fish were sampled in the months of January and June 2013 in rivers of the Ipanema National Forest, sub-basin of the Ipanema River, collected through sieves and trawls. 91 individuals were captured, distributed in one order and two families 52 from Hypostomus ancistroides and 39 from Corydoras flaveolus. The results of this study showed that the Hypostomus ancistroides is outside of what is expected for parameter "a" 0.0058 (0.0043-0.0072), and Corydoras flaveolus is outside of what is expected for parameter "b" 3.75 (3.38-4.11), these date consisted of important biological information for freshwater fish, as this relationship justifies the search for mathematical improvement of the indices, as well as standardization of the types of condition factor used in studies with the same species, facilitating comparisons and, consequently, management and conservation actions.
\end{abstract}

Keywords: Freshwater fish; rivers; Hypostomus ancistroides; Corydoras flaveolus. 


\section{RESUMO}

A relação peso-comprimento é uma importante ferramenta nos estudos de biologia, fisiologia e ecologia de peixes, pois esta relação é útil para determinar o peso e a biomassa, indicando condições e permitindo comparações entre o crescimento de diferentes populações, além disso, esta relação também pode ser utilizada para avaliar o grau de saúde da espécie no ambiente. 0 objetivo deste trabalho foi apresentar dados não publicados sobre a relação peso-comprimento (LWRs) das espécies Hypostomus ancistroides e Corydoras flaveolus. Os peixes foram amostrados nos meses de Janeiro e Junho de 2013 em rios da Floresta Nacional de Ipanema, sub-bacia do rio Ipanema, coletados através de peneiras e rede de arrasto. Foram capturados 91 individuos, distribuidos em uma ordem e duas familias, sendo 52 de Hypostomus ancistroides e 39 de Corydoras flaveolus. Os resultados deste estudo mostraram que Hypostomus ancistroides está fora do que é esperado para o parâmetro "a" 0.0058 (0.0043-0.0072), e Corydoras flaveolus está fora do que é esperado para o parâmetro "b" 3.75 (3.38-4.11), esses dados consistiram em importantes informações biológicas para os peixes de água doce, pois essa relação justifica a busca de aprimoramento matemático dos índices, bem como padronização dos tipos de fator de condição utilizados em estudos com as mesmas espécies, facilitando comparações e, consequentemente, ações de manejo e conservação destas.

Palavras chaves: Peixes de agua doce; rios; Hypostomus ancistroides; Corydoras flaveolus.

\section{RESUMEN}

La relación peso-longitud es una herramienta importante en los estudios de biología, fisiología y ecología de los peces, ya que esta relación es útil para determinar el peso y la biomasa, indicar condiciones y permitir comparaciones entre el crecimiento de diferentes poblaciones, además, esta relación también puede ser utilizado para evaluar el grado de salud de las especies en el medio ambiente. El objetivo de este estudio fue presentar datos no publicados sobre la relación peso-longitud (LWR) de las especies Hypostomus ancistroides y Corydoras flaveolus. Los peces fueron muestreados en los meses de enero y junio de 2013 en ríos del Bosque Nacional Ipanema, subcuenca del río Ipanema, recolectados a través de tamices y redes de arrastre. Se capturaron 91 individuos, distribuidos en un orden y dos familias, 52 de Hypostomus ancistroides y 39 de Corydoras flaveolus. Los resultados de este estudio mostraron que Hypostomus ancistroides está fuera de lo esperado para el parámetro "a" 0.0058 (0.0043-0.0072), y Corydoras flaveolus está fuera de lo esperado para el parámetro "b" 3.75 (3.38-4.11), estos la fecha consistió en información biológica importante para peces de agua dulce, ya que esta relación justifica la búsqueda de una mejora matemática de los índices, así como la estandarización de los tipos de factores de condición utilizados en estudios con la misma especie, facilitando las comparaciones y, en consecuencia, el manejo y la conservación comportamiento.

Palabras clave: Peces de agua dulce; ríos; Hypostomus ancistroides; Corydoras flaveolus.

\section{INTRODUCTION}

The state of São Paulo has the largest remaining Atlantic Forest area, located mainly in state parks, ecological stations and Conservation Units (CU) (1). The present work is part of an important UC known as the Ipanema National Forest, belonging to the sub-basin of the Ipanema River, which is part of the Sorocaba river basin. The length-weight ratio is an important parameter of fish populations and their applications range from estimating the weight and length of an individual to indications of fish condition (condition factor) (2). The condition factor is an indicator of the health status of an individual and its value reflects the recent nutritional conditions and / or the spending of reserves on cyclical activities, analyzing the relationships with the environmental conditions and the behavioral aspects of the species $(3,4)$.

Given the above, the objective of this study was to present unpublished data on the weight-length relationship (LWRs) of two species Hypostomus ancistroides and Corydoras flaveolus sampled in rivers of the Ipanema National Forest.

\section{MATERIALAND METHODS}

The Ipanema National Forest is a Federal Conservation Unit (CU) administered by the Chico Mendes Institute for Biodiversity (ICMBio), located in the municipalities of Araçoiaba da Serra, Iperó and Capela do Alto, covering an area of 5,385 ha of the Atlantic Forest biome, inserted in the Water Resources Management unit 10 (UGRHI 10), corresponding to the hydrographic basins of the Sorocaba river and the center of the Tietê (5). 
The collection of samples was made in January and July 2013 within the Ipanema National Forest, belonging to the subbasin of the Ipanema River, in the Tietê river basin, using a 50 by $50 \mathrm{~cm}$ sieve with a mesh of $1 \mathrm{~cm}$ and net of trawl of 3 meters in length and $5 \mathrm{~mm}$ mesh. After capture, the fish were euthanized in the field under the effect of the benzocaine anesthetic, after that they were weighed with the aid of on a digital balance $(0,00001 \mathrm{~g}$ precision) and measured with the aid of a tape measure and analogical caliper $(0,1 \mathrm{~mm}$ precision) and then placed in $10 \%$ formaldehyde solution for fixation. In the laboratory, the samples were transferred to alcohol 70\% for preservation. The length-weight ratio for both species was based on Keys (6). Species identification was based on Smith et al (7), and all the collected vouchers were deposited in the fish collection at the Functional and Structural Ecology of Ecosystems Laboratory at Universidade Paulista, Sorocaba campus, São Paulo, Brazil (catalog numbers LEEF 0072-0073). All of the collections were carried out with authorization of the IBAMA license (Authorization № 658/2015).

In addition, the choice of the TL (total length) measure was adopted in the study, as it does not make the results generated unfeasible, taking into account the different types of length measures that can be used for studies of the length-to-weight ratio (LWR). The type of length used varies according to the study. In this work, we chose to use the total length, as it is a measure that includes the entire tail fin and all individuals sampled in this study had this structure intact. As an example, the following studies used the total length to calculate the RLT: $(8,9)$.

For the weight / length ratio, the formula was applied: Wt = a Lt b (10), where Wt corresponds to weight, Lt, length, a, the factor related to the degree of fattening of individuals and $b$, to the allometry coefficient, related to the growth of individuals. The values of a and b were estimated using the least squares method (predictive model), after logarithmic transformation in the Neperian base of the following equation: In Wt $=$ In $a+b$ In $L t(11)$.

\section{RESULTS}

A total of 91 specimens were captured, distributed in one orders (Siluriformes) and two families (Loricariidae and Callichthyidae, representing two species, 52 of Hypostomus ancistroides and 39 of Corydoras flaveolus (Table 1). Comparing the results of parameters a and b with the Baesian analysis, Hypostomus ancistroides presented measurements 0.0058 (0.0043-0.0072) which is outside of what is expected for parameter a, with the expected value for this parameter $\mathrm{a}=0.01862$ (0.00977 - 0.03550), according to data Fish Base, while Corydoras flaveolus presented measurements 3.75 (3.38-4.11) which is outside of what is expected for parameter $b$, with that expected for this parameter $b=3.12(2.94-$ 3.30). New records of maximum length for both species were raised.

Table 1. Relationship of total length ( $\mathrm{cm}$ ) and weight ( $\mathrm{g}$ ) for the two species sampled in rivers of the Ipanema National Forest, where $\mathrm{W}=\mathrm{aL}^{\mathrm{b}}$ and $\mathrm{n}=$ number of specimens used in the analysis, $\mathrm{R} 2$ = correlation coefficient. The length-weight ratios for the two species were significant in $\mathrm{p}<0.0$.

\begin{tabular}{cccccccc}
\hline Family & Taxa & $\mathbf{n}$ & WT range $(\mathbf{g})$ & TL range (cm) & a (95\% CI) & b (95\% CI) & $\mathbf{R}^{\mathbf{2}}$ \\
\hline Loricariidae & Hypostomus ancistroides & 52 & $0.20-198.84$ & $3.30-24.30$ & $0.0058(0.0043-0.0072)$ & $3.15(3.04-3.27)$ & 0.984 \\
Callichthyidae & Corydoras flaveolus & 39 & $0.22-2.20$ & $2.80-4.90$ & $0.0050(0.0030-0.0070)$ & $3.75(3.38-4.11)$ & 0.922 \\
\hline
\end{tabular}

\section{DISCUSSION}

The individuals of the species Hypostomus ancistroides, a species described with specimens from the Sorocaba river basin (12), presented, according to the Baesian analysis, that the parameter "a" is out of expectations, indicating that the body shape is atypical for the species in question (13), with a lower degree of fattening. The " $b$ " factor of individuals of the Corydoras flaveolus species was 3.75, which is not in the 2.5 to 3.5 range, considered ideal (14), indicating that the species did not show an expected ideal growth. The size range covered for the Corydoras flaveolus was small (ie 3.38 to $4.11 \mathrm{~cm}$ ). Values less than or greater than 3.0 indicate individuals who, over the course of growth, become more "longilines" or "round", respectively. Therefore, the LWR for this species should be considered preliminary and needs to be verified in future studies.

These changes may be related to seasonal differences that may be affected by temporal variations in food availability, food activity, environmental factors (such as water temperature, salinity and nutrition), population density or sex that may affect the estimated values of the relationships obtained $(15,16)$. 
Therefore, the weight and length ratio can also be used to assess the degree of well-being or health of the species through the condition factor, which may reflect recent nutritional conditions, expenditure of energy reserves, parasitic infections and others. This index can also indicate the reproductive period of species, periods of changes in diet and accumulation of fat, as well as seasonal changes in environmental conditions $(17,18)$.

Although the sample size of each species was relatively low, the $r^{2}$ values were considered acceptable for both species (19), with "b" values in the LWR between 3.04-3.27 and 3.38 -4.11, respectively (Table 1). Although easy to obtain, data on LWRs are scarce for several species in the Neotropical region, therefore, these data consist of important biological information for freshwater fish (20).

\section{REFERENCES}

1. IBF - Instituto Brasileiro de Florestas. Bioma Mata Atlântica. Acesso em: 02 Dez de 2018. Acesso em: https://www. ibflorestas.org.br/bioma-mata-atlantica

2. Lemos JRG, Tavares-Dias M, Marcon JL, Lemos PEM, Affonso EG, Zaiden SF. Relação peso-comprimento e fator de condição em espécies de peixes ornamentais do rio Negro, Estado do Amazonas, Brasil. CIVA. 2006; $721-725$.

3. Gomiero LM, Braga FMS. 2005. The condition fator of fishes from two river basins in São Paulo state, Southeast of Brazil. Acta Sci. Biol. Sci. 2005; 27(1):73-78. https://doi.org/10.4025/actascibiolsci.v27i1.1368

4. Camara EM, Caramaschi EP, Petry AC. Fator de condição: Bases conceituais, aplicações e perspectivas de uso em pesquisas ecológicas com peixes. Oecologia Australis. 2011;15(2):249-274. https://doi:10.4257/0eco.2011.1502.05

5. InstitutoChicoMendesdeConservaçãodaBiodiversidade-ICMBio,2017.PlanodeManejodaFLONARevisão.Disponível em: https://www.icmbio.gov.br/portal/images/stories/planodemanejo/pmflonadeipanemavolIdiagnostico.pdf.

6. Keys AB. The length-weight relation in fishes. Proceedings of the National Academy of Science of the United States of America. 1928; 14: 922-925. https://doi.org/10.1073/pnas.14.12.922

7. Smith WS, Biagioni RC, Halcsik L. Fish fauna of Floresta Nacional de Ipanema, São Paulo State, Brazil. Biota Neotropica. 2013; 13(2):175-181. https://doi.org/10.1590/S1676-06032013000200016

8. Koutrakis ET, Tsikliras AC.(2003). Length-weightrelationships of fishes from three northern Aegean estuarine systems (Greece). Journal of Applied Ichthyology, 19(4), 258-260. https://doi.org/10.1046/j.1439-0426.2003.00456.x

9. Oliva-Paterna FJ, Torralva M, Carvalho ED. (2009). Length-weight relationships for 20 species collected in the Jurumirim reservoir (Paranapanema Basin, Brazil). Journal of Applied Ichthyology, 25(3), 360-361. https://doi. org/10.1111/j.1439-0426.2009.01194.x

10. Le-Cren ED. The lenght-weight relationship and seasonal cycle in gonad weight and conditions in the perch. Jour. Anim Ecol. 1951; 20(2):201. https://pdfs.semanticscholar.org/4bb0/afdc96c10bb39487f9b7d06947332a94ad16. $\underline{\mathrm{pdf}}$

11. Santos EP Dos. Dinâmica de populações aplicada à pesca e psicultura. São Paulo, Hucitec: Ed. Univ. São Paulo; 1978.

12. Ihering RV. Algumas espécies novas de peixes d'agua doce (Nematognatha) (Corydoras, Plecostomus, Hemipsilichthys). Revista do Museu Paulista. 1911; 8:380-404.

13. Froese R, Thorson JT, Reyes Jr RB. A Bayesian approach for estimating length-weight relationships in fishes. Journal of Applied Ichthyology. 2014; 30(1):78-85. https://doi.org/10.1111/jai.12299

14. Froese R. Cube law, condition factor and weight-length relationships: History, meta-analysis and recommendations. Journal of Applied Ichthyology. 2006; 22(4):241-253. https://doi.org/10.1111/j.1439-0426.2006.00805.x 
15. Dieb-Magalhães L, Florentino AC, Soares MGM. Relações comprimento-peso e comprimento na primeira maturidade para nove espécies de peixes de lagos de várzea na Amazônia Central (bacia Amazônica, Brasil). Journal of Applied Ichthyology. 2015; 31:1182-1184. https://doi.org/10.1111/jai.12919

16. Freitas TMS, Prudente BS, Montag LFA. Relação comprimento-peso em dez espécies de peixes do rio Nhamundá, na Bacia Amazônica, Brasil. Acta Amazonica. 2017; 47(1):75-78. https://doi.org/10.1590/1809-4392201601272

17. Gomiero LM, Braga FMS. Relação peso-comprimento e fator de condição para Cichla cf. ocellaris e Cichla monoculus (Perciformes, Cichlidae) no reservatório de Volta Grande, rio Grande -MG/SP. Acta Sci Biol Sci. 2003; 25(1):79-86. https://doi.org/10.4025/actascibiolsci.v25i1.2119

18. Rêgo ACL, Pinese OP, Magalhães PA \& Pinese JF. Relação peso-comprimento para Prochilodus lineatus (Valenciennes, 1836) e Leporinus friderici (Bloch, 1794) (Characiformes) no reservatório de Nova Ponte -EPDA de Galheiro, rio Araguai, MG. Revista Brasileira de Zoociências. 2008; 10(1):13-21. https://periodicos.ufjf.br/index.php/ zoociencias/article/view/24080

19. Azevedo Santos VM, Coelho PN, Brambilla EM, Lima FP, Nobile AB, Britton JR. Length-weight relationships of four fish species from the upper Paraná River basin, Southeastern Brazil. Journal of AppliedIchthyology. 2018; 34(1):237239. https://doi.org/10.1111/jai.13542

20. Manoel PS, Brambilla EM. Length-weight relationships of five fish species of headwater streams from upper Paraná River Basin, Southeastern Brazil. Journal of Applied Ichthyology. 2018; 34(5):1225-1227. https://doi.org/10.1111/ jai.13747 